\title{
The Changing Facets of Corporate Governance and Corporate Social Responsibilities in India and their Interrelationship
}

\author{
P.K. Haldar, Lokanath Mishra \\ Tripura University, (A Central University), Suryamaninagar, Agartala, Tripura, India \\ Institute of Management, J.K. Lakshmipat University, Jaipur, Rajasthan, India \\ pkhaldar@rediffmail.com
}

\begin{abstract}
CG and CSR can be described as two sides of the same coin. Better governance leads the corporates to behave responsibly for the wellbeing of all the stakeholders. CSR is the medium through which corporates address the large group of stakeholders. Corporate Social Responsibility (CSR) moving far ahead from its age old domain of philanthropy and charity has now reached to a new hallmark of Corporate responsiveness and action to social issues and demand for sustainability in order to advance further towards a new era of collective future action for factoring the sustainable business strategy for good governance and development of the society and its people. The recent changing in the laws in India related to CSR and CG practices in India triggers this study to determine the relationship between them and also measure the influence of governance attributes on CSR practices of Indian corporates. The BSE SENSEX companies in India are the leaders in good governance practices and also the flag bearers in carrying out major CSR activities even when the CSR was not mandatory in India. The influence of corporate board attributes like Board Size, Board independent, Chairman-CEO duality, Female representative in corporate board, multiple directorships, and Promoter and directors shareholding on Corporate Social Responsibility measured through multiple regression analysis. The results revealed that chairman-CEO duality and the present of female directors in corporate board significantly influence of CSR contribution. Before generalization of the result of study further research could be undertaken taking a large group of Indian companies and wider corporate governance variables.
\end{abstract}

Keyword: Corporate Governance, Corporate Social Responsibility, Interrelationship, Board of Directors, Board Attributes

\section{Introduction}

Corporate Social Responsibility: Corporate social responsibility is not a new concept in India. However, what is new is the shift in focus from making profits to meeting societal challenges. Every business operates in an society and uses its environment and owes a responsibility towards improvement of healthy ecosystems, promoting social inclusiveness and equity, upholding ethical practices and good governance by means of preserving the environment, minimizing the wastage of natural resources, recycling of products, helping the needful and working for the larger interest of the society by promoting, education, healthcare, and livelihood etc. HR Bowen's 'Social Responsibilities of the Business' in 1953 is the first academic literature in India emphasized on CSR. Since then, there has been continuous debate and discussion on CSR and its purview worldwide but no universal definition of CSR evolved. The World Bank Group, defined CSR as , "Corporate Social responsibility is the commitment of business to contribute to sustainable economic development by working with employees, their families, the local community and society at large, to improve their lives in ways that are good for business and for development".

Corporate Social Responsibility (CSR) moving far ahead from its age old domain of philanthropy and charity has now reached to a new hallmark of Corporate responsiveness and action to social issues and demand for sustainability in order to advance further towards a new era of collective future action for factoring the sustainable business strategy for good governance and development of the society and its people. To ensure all round development and sustainable economic, environment and social growth and inclusiveness Government of India made it mandatory for all the corporates public as well as private to take up CSR initiative. India becomes first country in the world to mandate corporate social responsibility spending, through a statutory provision under clause 135 of companies Act, 2013. This applies to every company in 
India having a net worth of Rs. 500 Crore or more, a turnover of Rs. 1000 Crore or more or a net profit of Rs. 5 Crore or more during any financial year. This land mark legislation may provide a right direction in CSR spending of Indian corporates in coming years. The schedule VII of the new companies Act, 2013 also provided information about activities which may be included by companies in their Corporate Social Responsibility Policies.

Corporate governance: Corporate governance stands for Commitment to wellbeing and progress of all stakeholders. Companies that have followed the principles of corporate governance have consistently earned high returns increased their net worth and enhanced their shareholders wealth, dealt ethically with customers, government and business partners and maintained and updated their professional management culture, system and process and accomplished excellence. Given the complexity of today's organizations, there is no simple or straightforward task the boards need to perform. Today, board effectiveness is a key performance driver of the Indian companies. There is growing demand for more transparency in board decision. It was the securities and Exchange Board of India (SEBI) which regulates India's Stock Market, had initially mandated the adherence of clause 49 of corporate governance for all listed companies from April 1, 2004. Clause 49 is basically a regulation that calls for an increase in the number of independent directors serving on the boards of Indian companies to ensure more transparency and better accountability limited to only listed companies in India. However the recent overhaul in the corporate governance norms for all companies under the new companies Act, 2013 enacted on August 30, 2013 and the consequent amendment by Securities and exchange Board of India to Clauses 35B and 49 of the Equity Listing agreement dated April 17,2014 triggers this study to determine the interrelationship of corporate governance on corporate social responsibilities practices of Indian companies.

Corporate governance and corporate responsibility Interrelationship: Corporate governance and corporate responsibility are intertwined. Corporate social responsibility (CSR) is now becoming much more a part of mainstream corporate governance as there is a recognition that a company cannot - in the long-term operate in isolation from the wider society in which it operates. Sir Adrian Cadbury, 2002 remarked that: 'The broadest way of defining social responsibility is to say that the continued existence of companies is based on an implied agreement between business and society' and that 'the essence of the contract between society and business is that companies shall not pursue their immediate profit objectives at the expense of the longer-term interests of the community' The wider stakeholder community is also making increasing demands that board of governance be held accountable for the social and environmental impacts of their operations. The agency theory of corporate governance held directors accountable to shareholders whereas the stewardship theory of corporate governance expects from the board to consider the views of other stakeholders.

There is conflicting relationship between CG and CSR and depends upon how it has been defined. If we will look at micro view it concerns the relationship of company to its shareholders, and the goal of wealth maximization will come into play. Whereas if we will look at macro view the relationship of the company to extends to the society at large and satisfying the broad group of stakeholders include employees, customers, suppliers, local community, interest groups, government, . A careful analysis of the relationship shows that corporate governance covers a range of issues for the protection of the interest of shareholders and stakeholders. At the same time CSR can be regarded as extension of corporate governance Stewardship theory. However it can be conclude that CG and CSR are overlapping and it is highly difficult to make them separate. The corporates who have well-formed corporate governance program in place, probably taking care of most CSR issues and vice versa. In light of the recent overhauling and amendment in the laws related to corporate governance and Corporate Social responsibility practices in India, corporate governance is needed to incorporate and manage CSR in corporate policy, practices and reporting. The legal mandate for compulsory CSR spending will take CSR factors increasingly moving to board room for decision making. Driven largely by CSR business cases, good governance will come to include aspects of CSR. It will be interesting to see how the corporate boards are addressing the issue and making the CSR expenditure in the larger interest of society, environment and economic sustainability. The proposed study is designed to study the influence of corporate governance on CSR disclosure of selected Indian Companies. 


\section{Literature Review}

The extensive study of Corporate Governance literature shows that board demography had linked with various aspects of organizational financial, social, environmental performance and its impact studied well. The growing amount of contemporary research on board suggests that diversity among board members has the potential to increase board effectiveness and there by performance. The recent amendments in Corporate Governance codes under new Companies Act, 2013 in India and subsequent modification in Clause 49 and Clause 35B by SEBI (Securities Exchange Board of India) put the emphasis on composition of corporate board and larger representation by Independent directors. The companies with Executive Directors as Chairman than half of the board members should be independent directors and if the Non-executive directors are the chairman then at least one-third of the board member should constitute of Independent directors. The new corporate governance code also emphasis of having one of the directors should be female member. One of the pioneer studies in the area of Corporate Governance by Jensen \& Meckling (1976) depicted that there is an agency relationship between owners, independent board members, and insiders, stock ownership can have a positive incentive effect to align the interests of both groups with shareholders. There are various other studies which identified the factors that impact the effectiveness of the board such as board size Klein 2002b; director attendance Allen (2004); number of board appointments (Young et al., 2003; Dunn \& Sainty, 2004; Fich \& Shivadasani, 2006). Having the firm's Chief Executive officer also serve as the Chairperson of the Board (called CEO/COB duality) can also compromise the independence of the board and the audit committee causing both mechanisms to be less effective (Farber, 2005). Literature also shows that board demography also linked with financial performance and found positive correlation between CG and firm performance.

The corporates which address the concern of larger group of stakeholders through their CSR program. In the recent past India one of the first country in world to make it mandatory on part of corporates to invest at least $2 \%$ of their annual profits towards the environmental sustainability, community development, health care programs for the society and environment in which they operates. The existing literature on the correlating the CSR with companies financial performance found that attributes like net profit, net worth and turnover, leverage, return on investment, return on equity are significantly related to the extent of corporate disclosure (Mishra Supriti \& Damodar, 2010; Hosain \& Reaz, 2007; Teoh \& Shiu, 1990; Adamas et al., 1998; Purushotahman et al., 2000; Khilf \& Soussi, 2010). Whereas review of other literature concluded that the relationship between these companies attributes and CSR disclosures are varies across industries and time period, may not have always a significant relationship (Gray et al., 1996; Suwaidan, 2004). The literature linked Corporate Governance to financial performance and CSR with financial performance, and it is the board of directors who are at the helm of corporate affairs has a major says on CSR policy through which they address the concern of larger group of stakeholders. The proposed study made a point to find the impact of corporate board attributes on CSR. There is a very few study in Indian context of linking CG with CSR; however we found most of the studies in foreign context. Gul and Leung (2004), Byard, Li \& Weintrop (2006), and Htay et al. (2012); concluded that higher proportion of independent board has positive and significant impact to CSR disclosure.

Jamali et al. (2008) in their study of top managers of eight corporations operating Lebanon concluded that the majority of managers conceive CG as a necessary pillar for sustainable CSR. The corporate boards are increasingly seen as responsible for matter relating to CSR and sustainability (Ingley, 2008). The study by Kakabadse (2007) concluded that CSR is a critical items on boards agendas while Elkington (2006) remarked that board have major responsibilities in achieving CSR objectives but Yoshikawa and Phan (2003) gave an opposite view and argued that larger size of board is ineffective and will create ineffective coordination and communication less cohesive and more difficulties in coordination. MacMillan et al. (2004) concluded that in broader view corporate governance emphasize that every business is responsible towards the different stakeholders that provide it with the necessary resources for its survival, competitiveness, and success. In Regard to studies available on measuring the impact of corporate governance factors on CSR disclosure by firms, even though limited, research still suggests that board diversity to a certain extent can influ ence social and environmental aspects of the business. The literature shows that considerable amount CG influence on CSR in the study conducted by Ayuso and Argandona (2009), Dunn and Sainty (2009), and Huang 2010. In their study regard to board size and board independence Hurther (1997) concluded that smaller size of board and independence from management will result in a positive impact on the monitoring function. While 
studying the relationship between board diversity and environmental corporate social responsibility post et al. (2011); finds a positive relationship between certain board attributes and ECSR. Bear, Rahman \& Post (2010) examined both the board resource diversity and women and their effect on firms CSR ratings and the result supported that the board with women are positively related to CSR and not related to resources diversity, in another study Ibrahim \& Angelidies (2011); depicted that Board members gender have positive influence over the corporate social responsiveness. Fang, et al. (2010) in their study concluded that a firm with dynamic capabilities of relationship management can determine the effectiveness of alternative CSR strategies, in influencing organizational performance and Corporate governance and corporate social responsibilities functions of the board are complementary to each other in shaping the objective function of the organization (Beltratti, 2005).

However some literature shows that CG and CSR are independent of each other and found no significant relationship between board attributes to CSR disclosure (Meryawati, 2011; Lucyanda and Siagian, 2012). In an empirical study of the association between corporate governance and corporate social responsibility concluded that CSR measures do not affect CG, however a lagged measure of CG has a positive effect on CSR. In the same line another study by of 70 listed companies in Tehran Stock Exchange found that there is no significant relationship between the elements of corporate governance and social responsibility disclosure of Tehran companies. Mulyadi \& Anwar (2012) in their study of Indonesian Corporations depicted that board independence and institutional ownership do not have significant influence to CSR disclosure. In light of the mixed result from the study of literature and recent overhauling in the laws related to Corporate Governance and corporate social responsibility in India, the proposed study makes an attempt to examine the influence of corporate governance on CSR practices of Indian companies.

\section{Research Objectives:}

- To Study the corporate board demography of selected Indian Companies.

- To examine the influence of corporate board attributes on CSR practices.

\section{Methodology}

In line of research objective an empirical study was carried out to examine the influence of corporate board attributes on CSR Practices of selected Indian Companies. The present study is exploratory in nature and is based on secondary data. The companies listed in the BSE SENSEX, as on 31 $1^{\text {st }}$ December, 2014 has been considered to examine the corporate governance practices and its possible influence over corporate social responsibility practices. Out of 30 companies finally 24 companies selected for the proposed study after excluding banking and financial companies. The companies selected under the study covers wide range of Indian industries including automobiles, pharmaceuticals, consumer goods, power, energy, oil and natural gas, Information technology, and service sector giving wider representation and blue chip companies in their respective industries. These companies regarded as best practitioner of corporate governance as well as CSR practices from decades even when both are not mandatory in nature under Indian law and that's the reason behind taking these top most companies to study the interrelationship between corporate governance and CSR practices. The annual report of all the companies downloaded from their respective website. The list of sample companies given in the Annexure1. The CSR disclosure practices of sample companies were measured by establishing the disclosure index and the same was constructed on the basis of items listed in amended schedule VII of the companies Act, 2013, published on 27th Feb, 2014. On the basis disclosure index, a scoring sheet was prepared to record the social responsibility disclosure practices by sample companies. If a company discloses an item of information included in the index, it receives a score of 1 , and 0 if it is not disclosed. The CSR disclosure index given in the Annexure 2 at the end. To measure the influence of corporate governance on CSR practices 6 elements of corporate board characteristics were considered on the basis of literature review and latest amendments in corporate governance disclosure norms by the Govt. of India. Board characteristics are one of the important aspects of corporate governance. The following board characteristics are taken in to account for the proposed study.

Size of the Board (B-SIZE): It can be argued that a larger board is more likely to address agency problems because greater number of people will be reviewing management actions. So the Size of the Board taken as one of the demographic variable for this Study. This is measured as the number of directors in the company. 
Independence of the Board (INDPB): Board's independence from internal and external influences is critical and directly proportional for effective corporate governance. The Agency theory also suggests that a greater proportion of outside directors will be able to monitor any self-interested action by managers and so will minimize the agency costs. So, the Independence of the Board is taken here as another board characteristics. The Independence of Board is measured as the percentage of Independent directors over the total number of directors in the board.

Chairman-CEO Duality (CCDUAL): The agency theory says that the effectiveness of board monitoring may be reduced it the same person holds the Chief executive officers and chairman position, whereas the stewardship theory says that one person in both roles may improve firm performance because of better control over firm activities. Sol the CEO duality chosen to see its effect over firm performance as one of the attributes. This variable measured by assigning a value of 1 to a company if duality occurs and 0 other wise.

Directorship in more than one company (MDRP): The Independent directors generally accept the directorship in more than one board of different companies. It may lead to non-functioning and lead to division of time on more than one corporate affairs and may influence the firm performance. So, Directorship in more than one company taken as another board characteristic for this study. This is measured by assigning a value of 1 if at least one of the independence directors has at least two directorships outside the firm and 0 otherwise.

Table 1: Descriptive Statistics

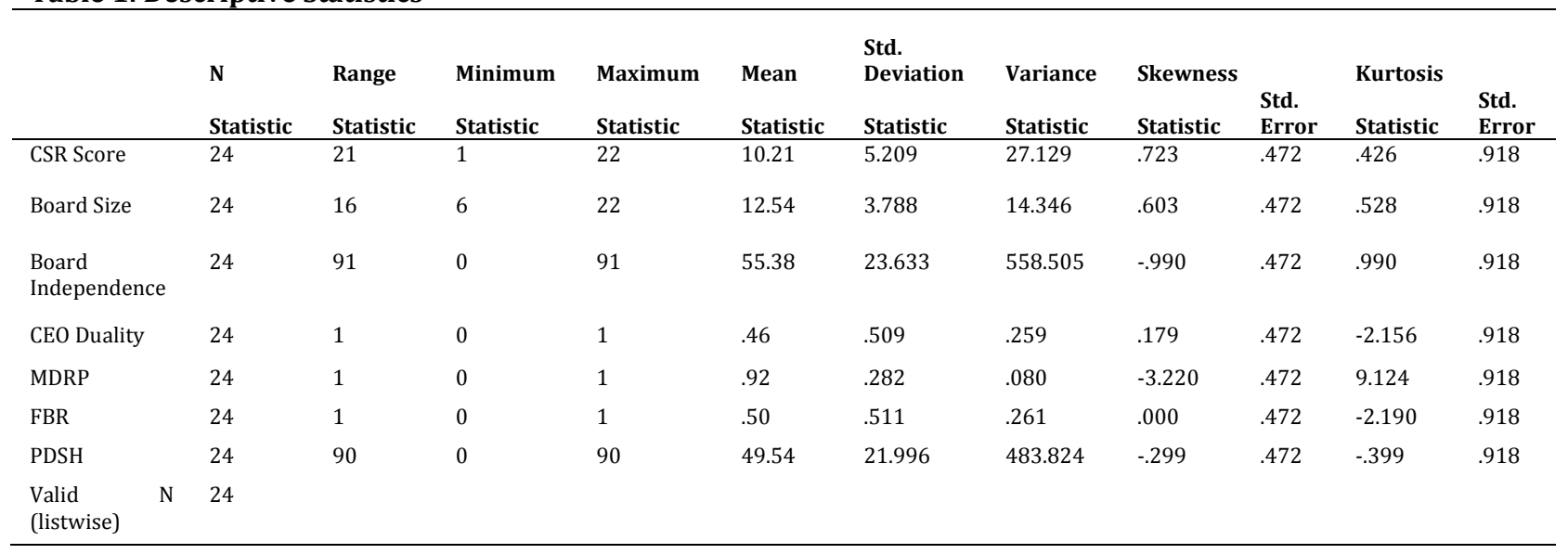

Female board representative (FBRP): The new companies Act, 2013 and the amendment of corporate governance norms by SEBI requires for at least one female director on the board to represent wider stakeholders perspective. While measuring the representation of female director, percentage of women directors was calculated as the sum of women directors on a given board divided by the total number of all directors on a given board.

Promoter \& Director Shareholding (PDSH): There are substantial portion of share capital employment by promoter and promoter cum directors in the companies. This is taken as one of the important board attributes which may influence the firm performance. The data were collected and entered in Excel Spreadsheet for further analysis. Descriptive statistics, simple and multiple regression analysis was done through using SPSS (20) software to measure the influence of Corporate governance attributes on CSR practices.

\section{Research Hypothesis:}

H01: Corporate board attributes like BSIZE, INDPB, PDSH, CCDUAL, MDRP and FBRP does not significantly influence CSR practices.

H11: Corporate board attributes like BSIZE, INDPB, PDSH, CCDUAL, MDRP and FBRP significantly influences of CSR practices. 


\section{Data Analysis and Interpretation}

With the aim to measure the influence of corporate governance attributes on corporate social responsibility practices of sample companies, descriptive statistics, and correlation and regression analysis carried out with the following results.

The above table represents the descriptive statistics for the different corporate board attributes drawn from 24 selected BSE Sensex companies. It can be seen from the above table that the average size of the board members is12.54, which represents the depth of board size in Indian companies, where as independent directors constitutes more than half of the board size i.e. 55.38. The greater the number of independent directors more transparency in governance can be expected from the corporate board. In term ownership from the board members the shard holding from promoter and directors constitutes $49.54 \%$. The promoters on the basis of their large scale holding of share of their respective companies also enjoys the chairman and chief executive officer position, which is quite evident from the result. The board executive and non-executive directors have their presence in multiple board of different companies and the result show that almost $92 \%$ directors have multiple directorship in different companies. Except for INDPB, PDSH and MDRP, all other variables are skewed to the right when presented in a probability distribution function with asymmetric evidence. The skewness for FBRP shows symmetrical. On the other hand for all the variable except MDRP have pletykurtic probability distribution functions with kurtosis value less than 3.

Table 2: Pearson Correlation Analysis

\begin{tabular}{llllllll}
\hline & CSR & BSIZE & INDPB & CCDUAL & MDRP & FBRP & PDSH \\
\hline CSR & 1 & & & & & & \\
BSIZE & .267 & 1 & & & & & \\
INDPB & .295 & -.112 & 1 & & & & \\
CCDUAL & -.202 & -.022 & .253 & 1 & & & \\
MDRP & -.017 & .085 & .090 & .277 & 1 & & \\
FBRP & $.646^{* *}$ & .214 & $.355^{*}$ & 0.84 & -.302 & 1 & \\
PDSH & -.162 & .220 & -.275 & -.311 & -.223 & -.141 & 1 \\
\hline
\end{tabular}

*. Correlation is significant at the 0.05 level (2-tailed).

**. Correlation is significant at the 0.01 level (2-tailed).

Table 3: Summary Results of Individual Regressions Analysis with CSR

\begin{tabular}{llllll}
\hline $\begin{array}{l}\text { Individual Regression Summary } \\
\text { Variables }\end{array}$ & Un-Std. Co-eff. B & Std. Error & Beta Co-efficient & t-stat & P-value \\
\hline (Constant) & 5.598 & 3.695 & & 1.515 & .144 \\
B.SIZE & .368 & .283 & .267 & 1.301 & .207 \\
(Constant) & 6.613 & 2.695 & & 2.454 & .023 \\
INDPB & .065 & .045 & .295 & 1.446 & .162 \\
(Constant) & 11.154 & 1.447 & & 7.710 & .000 \\
CCDUAL & -2.063 & 2.137 & -.202 & -.965 & .345 \\
(Constant) & 10.500 & 3.765 & & 2.789 & .011 \\
MDRP & -.318 & 3.933 & -.017 & -.081 & .936 \\
(Constant) & 6.917 & 1.174 & & 5.891 & .000 \\
FBRP & 6.583 & 1.660 & .646 & 3.965 & $.001 *$ \\
(Constant) & 12.112 & 2.691 & & 4.501 & .000 \\
PDSH & -.038 & .050 & -.162 & -.772 & .449 \\
\hline
\end{tabular}

Note* statistically significant $\alpha=0.01$ 
In line of result of the prior research on studying the relationship between various board attributes and CSR, our results confirmed the import relationship. There is a positive and significant correlation observed between FBRP and CSR practices. The earlier study by Bear, Rahman \& Post (2010), Ibrahim \& Angelidies (2011), and Fang et al. (2010) concluded that the female representative in board members have significant influence on CSR policies and practices of the companies. However it is important to note that the correlation between other corporate attributes shows negative or no correlation as given in the table. The mixed result from correlation analysis made us to investigate further the influence of corporate board attributes on CSR practices of sample companies and we had undertaken simple and multiple regression analysis. The CSR score was taken as dependent variable and corporate board attributes as representative of corporate governance like BSIZE, INDPB, CCDUAL, MDRP, FBRP and PDSH taken as independent variables.

The above table shows that there is a significant influence of (FBRP) female representative in the composition of Indian corporate boards on corporate social responsibility policy and practices. The recent amendment in the norms of corporate governance code and conducts and mandatory female nominee in the board of all Indian Companies is the right step in that regards. Whereas the other independent variables have no significant influence on CSR. Having the research objective to measure the influence of corporate governance on CSR policies and practices multiple regression analysis performed on the derived data using the CSR as dependent variable and BSIZE, INDPB, CCDUAL, MDRP, FBRP and PDSH independent variables to see the combined effect of these corporate board attributes as representative of corporate governance drivers.

Table 4: Summary of Multiple Regression Result with CSR as Dependent Variable

\section{Regression Co-efficient}

\begin{tabular}{|c|c|c|c|c|c|}
\hline \multirow[b]{2}{*}{ Variables } & \multicolumn{2}{|c|}{ Unstandardized Coefficients } & \multicolumn{3}{|c|}{$\begin{array}{l}\text { Standardized } \\
\text { Coefficients }\end{array}$} \\
\hline & B & Std. Error & Beta & t & Sig. \\
\hline (Constant) & 2.422 & 4.901 & & .494 & .628 \\
\hline BSIZE & .194 & .237 & .141 & .819 & .424 \\
\hline INDPB & .026 & .039 & .117 & .656 & .521 \\
\hline CCDUAL & -4.005 & 1.739 & -.391 & -2.302 & $.034^{*}$ \\
\hline MDRP & 4.370 & 3.376 & .237 & 1.294 & .213 \\
\hline FBR & 6.718 & 1.966 & .659 & 3.416 & $.003^{* *}$ \\
\hline PDSH & -.032 & .042 & -.137 & -.775 & .449 \\
\hline
\end{tabular}

a. Dependent Variable: CSR Score

b. Predictors: (Constant), PDSH, FBR, CEO Duality, Board Size, Board Independence, MDRP

C. R Squared: 0.594 and Adjusted R-Squared $=0.451$

d. *statistically significant at $\alpha=0.05 .{ }^{* *}$ Statistically significant at $\alpha=0.01$

The above table shows that more than half i.e. 59.4\% changes in the CSR policy and practices can be explained by the variation in the independent variables. When adjusted for degree of freedom, the variation in the board attributes can explain $45 \%$ of the changes in CSR policy and practices. This shows a strong influence of governance factors on corporate social responsibility programs, policies and practices carried out by the firms addressing the larger group of stakeholders. The Gender diversity in the board as well as the chairman and chief executive officer duality have significant influence over CSR, whereas the other board attributes like board size, board independence, multiple directorship and promoter and directors shareholding have no influence on various CSR activities taken out by the sample firms. The null hypothesis is rejected for two independent variables i.e. FBRP and CCDUAL which significantly influence the CSR practices, whereas null hypothesis accepted and alternate hypothesis rejected for other variables i.e. BSIZE, INDPB, MDRP and PDSH. Our results are in the line earlier study conducted by Bear, Rahman \& Post (2010); who has examined both the board resource diversity and women and their effect on firms CSR ratings and the result supported that the board with women are positively related to CSR. The results of existing literature also show diverse outcomes. The studies carried out by Ayuso and Argandona (2009), Dunn and Sainty (2009), Huang (2010), Hurther (1997), Post et al. (2011), Angelidies (2011), Fang, et al. (2010), and Beltratti (2005) concluded that board attributes significantly influence the CSR disclosures, whereas studies carried out by 
Mulyadi \& Anwar (2012) in their study of Indonesian Corporations depicted that board independence and institutional ownership do not have significant influence to CSR disclosure. Earlier studies by Meryawati (2011), Lucyanda and Siagian (2012) shows that CG and CSR are independent of each other and found no significant relationship between board attributes to CSR disclosure.

\section{Conclusion}

The study was proposed with an objective to study the interrelationship between CG and CSR and also the influence corporate governance on CSR disclosure practices in Indian Context. In the process of data collection it was observed that most of the companies are still not complying with corporate governance code and conducts in its true sense and the information like director's profile, director's shareholding, the family or other relationship between the board members if any are not disclosed by all. As per latest guidelines of SEBI and new Companies Act, 2013 every company should have female member as board representative however only half of the sample companies has female member as board representative. The Directors of a company should have multiple directorship in maximum of 10 other companies however it was observed that the same was not strictly followed. Though we found significant influence of two corporate board attributes board gender diversity i.e. female board representative and chairman and CEO duality, however CSR is always board driven, and it is the responsibilities of the board to cater various expectations of wider group of shareholders. A company without proper control mechanism, well established organization structure, cohesive leadership and fair governance practices cannot pursue CSR in its true sense, though it has made mandatory under law. In fact the mandatory CSR norms in India will give more edge to the corporate governance practices and compel the firms to cater the needs of the society at large, apart from internal stakeholders. The statutory changes in CG and CSR norms in India are at infant stage and it required some times before review of CG and CSR interrelationship and influence of one another. However it can be conclude that CG and CSR are overlapping and it is highly difficult to make them separate. The corporates who have well-formed corporate governance program in place, probably taking care of most CSR issues and vice versa.

\section{References}

Adamas, C. A., Hill, W. \& Roberts, C. B. (1998). Corporate Social Reporting Practices in Western Europe: Legitimating Corporate Behavior? British Accounting Review, 30(1), 1-12.

Allen, E. (2004). Evaluating the Corporate Board. Strategic Finance, 85(7), 37-43.

Ayuso \& Argandona. (2009). Responsible Corporate Governance: Towards a Stakeholder Board of Directors? Journal of Business Ethics, 10(2), 27-31.

Bear, S., Rahman, N. \& Post, C. (2010). The Impact of Board Diversity and Gender Composition on Corporate Social Responsbility and Firm Reputation. Journal of Business Ethics, 97, 207-221.

Beltratti, A. (2005). The complementarity between Corporate Governance and Corporate Social Responsbility. Geneva: The International Association for the Study of Insurance Economics.

Byard D., Li Y. \& Weintrop J. (2006). Corporate Governance and the Quality of Financial Analyst's Information. Journal of Accounting and Public Policy, 25, 609-625.

Dunn, P. \& Sainty, B. (2004). The Impact of Insider Power on Fraudulent Financial Reporting. Journal of Management, 30(3), 397-412.

Dunn, P. \& Sainty, B.(2009).The relationship among board of director characteristics, corporate social performance and corporate financial performance. International Journal of Managerial Finance, 5, 407-423.

Elkington, J. (2006). Governance for Sustainability. Corporate Governance: An International Review, 14, 522529.

Fang, S. R., Huang, C. Y. \& Huang, S. W. L. (2010). Corpoate Social resposbilitiy strategies, dynamic capability and organisational performance: Cases of top Taiwan-selected benchmark enterprises. African Journal of Business Management, 4(1), 120-132.

Farber, D. (2005). Restoring Trust After Fraud: Does Corporate Governance Matter? The Accounting Review, 80(2), 539-561.

Fich, E. M. \& Shivdasani, A. (2006). Are Busy Boards Effective Monitors? The Journal of Finance, 61(2), 689724. 
Gray, R., Owen, D. \& Adams, C. (1996). Accounting and Accountability : Changes and challanges in Corporate Social and Environment Reporting. Prentice-Hall International (UK) LTd, London.

Gul, F. A. \& Leung, S. (2004). Board Leadership, Outside Directors' Expertiseand Voluntary CSR Disclosure. Journal of Accounting and Public Policy, 23, 351-379.

Hossain, M. \& Reaz, M. (2007). The determinants and characteristics of voluntary disclosures by Indian companies. Corporate Social Responsbility and Environmental Management, 14(5), 274-288.

Htay , S. N. N., Rashid, H. M. A., Adnan, M. A. \& Meera, A. K. M. (2012). Impact of Corporate Governance on Social and Environmental Information Disclosure of Malaysian Listed Banks: Panel Data Analysis. Asian Journal Finance \& Accounting, 4(1), 1-24.

Huang, C. J. (2010). Corporate Governance, Corporate Social Responsbility and Corporate Performance. Journal of Management \& Organisation, 16, 641-655.

Hurther, J. (1997). An empirical test of the effect of board size on firm efficiency. Ec Letter, 54, 259-264.

Ibrahim, N. A. \& Angelidis, J. P. (2011). Effect of Board Members gender on Corporate Social Responiveness orientation. Journal of Applied Business Research, 10, 35-40.

Ingley, C. (2008). Company Growth andn Board Attributes to Corporate Socia Responsbility. International Journal of Business Governance and Ethics, 4, 17-39.

Jamali, D., Safieddine, A. \& Rabbath, M. (2008). Corporate Governance and Corporate Social Responsbility Synergies and Interrelationship. Journal Compilation, 16(5), 443-459.

Jensen, M. \& Meckling, W. (1976). Theory of the Firm: Managerial Behaviour, Agency Costs, and Ownership Structure. Journal of Financial Economics, 3, 305-360.

Kakabadse, A. P. (2007). Being Responsbile: Boards are reexamining the bottom line. Leadership in Action, 27, 3-6.

Khilf, H. \& Souissi, M. (2010). The Determinants of Corporate Disclosure: A Meta-Analysis. International Journal of Accounting and Information Management, 18(3), 198-219.

Klein, A. (2002b). Economic Determinants of Audit Committee Independence. The Accounting Review, 77(2), 435-452.

Lucyanda, J. \& Siagian, L. G. P. (2012). The Influence of Company Characteristics Towards Corporate Social Responsbilitiy Disclosure. Proc2012 International Conference on Business and Management, (601619).

MacMillan, K., Money, K., Downings, S. \& Hillenbrand, C. (2004). Giving Your Organisation SPIRIT: An overview and call to action for directors on issues of corporate governance, corporate reputation and corporate responsbility. Journal of General Management, 30, 15-42.

Meryawati, F. (2011). Pengaruh Corporate Governancedan profitabilities terhadap pengungkapan tanggung jawab sosial perusahaan yang terdafter di Bursa Efek Indonesia. Skripsi.1-61.

Mishra, S. \& Damodar, S. (2010). Does Corporate Social Responsibility Influence Firm Performance of Indian Companies. Journal of Business Ethics, 95(4), 571-601.

Mulyadi, S. M. \& Yunita, A. (2012). Influence of Corporate Governance and Profitability to Corporate CSR Disclosure. International Journal of Arts and Commerce, 1(7), 29-35.

Post, C., Rahman, N. \& Rubow, E. (2011). Green Governance: Board of Directors Composition and Environmental Corporate Social Responsbility. Business \& Society, 50, 189-223.

Purushotahman, M., Phil, H. \& Ross, T. (2000). Determinants of Corporate Social Reporting Practices of Listed Singapore Companies. An Accounting Review, 12(2), 101-103.

Suwaidan, M. (2004). Social Responsbility Disclosure and Corporate Characteristics: The Case of Jordanian Industrial Companies. International Journal of Accounting, Auditing and Performance Evaluation, $1(4), 229-254$.

Teoh, H. Y. \& Shiu, G. Y. (1990). Attitutde towards Corporate Social Responsbility and Perceived Importance of Social Responsbility Information Characteristics in a Decission Context. Journal of Business Ethics, 9(1), 71-77.

Yoshikawa, T. \& Phan, P. H. (2003). The Performance Implications of Ownership-driven Governance Reform. European Management Journal, 21(6), 698-706.

Young, M. A. (2003). How Can Board Members Be Empowered If They Are Spread Too Thin? S.A.M. Advanced Management Journal, 68(4), 4-11. 


\section{Annexures}

\begin{tabular}{ll} 
1. List of Sample Companies \\
\hline S/N & Name of Companies \\
\hline 1 & Bajaj Auto Ltd. \\
2 & Bharat Heavy Electricals Ltd. \\
3 & Bharati Airtel Ltd. \\
4 & Cipla Ltd. \\
5 & Coal India Ltd. \\
6 & Dr. Reddy's Laboratories Ltd. \\
7 & GAIL(India) Ltd. \\
8 & Hero Motocorp Ltd. \\
9 & Hindalco Industries Ltd. \\
10 & Hindustan Unilever Ltd. \\
11 & ITC Ltd. \\
12 & Infosys Ltd. \\
13 & Larsen \& Turbo Ltd. \\
14 & Mahindra \& Mahindra Ltd. \\
15 & NTPC Ltd. \\
16 & Oil \& Natural Gas Corporation Ltd. \\
17 & Reliance Industries Ltd. \\
18 & SesaSterlite Ltd. \\
19 & Sun Pharmaceutical Industries Ltd. \\
20 & Tata Consultancy Services Ltd. \\
21 & Tata Motor Ltd. \\
22 & Tata Power Company Ltd. \\
23 & Tata Steel Ltd. \\
24 & Wipro \\
\hline
\end{tabular}

\section{CSR Disclosure Index}

\begin{tabular}{ll} 
SL. NO & Particulars/ Company \\
\hline A & Humanity, Eradication of poverty, Free meals \\
1 & Food relief foundation \\
2 & Free distribution of meals programs \\
3 & Contribution to NGO for Mid-day meal programs \\
B & Health Care Programs \\
1 & Preventive health care and Health Care education programs \\
2 & Sanitation Programs \\
3 & provision of safe drinking water \\
4 & Combating human immunodeficiency, HIV/AIDS/Cancer \\
5 & Support and training to medical staff for excellence \\
6 & Free Medical Camps/Mobile Medical Van \\
7 & Free Distribution of Medicines and other medical care \\
8 & Reducing Child mortality/improving maternal health \\
C & Primary Education \& Vocational Training \\
& communities
\end{tabular}


Skill enhancement programs

Adult literacy programs

University/College/School Alliances

Academic Industry Interface Programs

Funds given for technology incubators/Scholarship to meritorious students

Construction /Renovation of School/College Building

Community Development

Promoting gender equality

empowering women

Setting up of homes and hostels, orphanage, Day care

Benefit of armed forces veterans, war widows \& their dependents

Social schemes for senior Citizens

Environment Sustainability

Protection of Flora and fauna

Animal welfare

Agro forestry

Pollution decrease

Water conservation/purification

Go green projects

\section{Rural development Projects \& Others}

Agricultural Developments

Rural Non-farm employment

Rural Industries and Micro-Finance

support for Government initiated rural development programs

Promotion of Sports, Arts \& Culture

Protection of national heritage, art and Culture

Restoration of building and sites of historical importance

Setting up of public libraries

Promotion and development of traditional arts \& handicrafts

Promotion of rural sports

Contribution towards promotion of National/Olympic/Para-Olympic Sports

Contribution to Different funds

Prime Minister's National Relief fund

Fund for socio-economic development

Relief Fund 